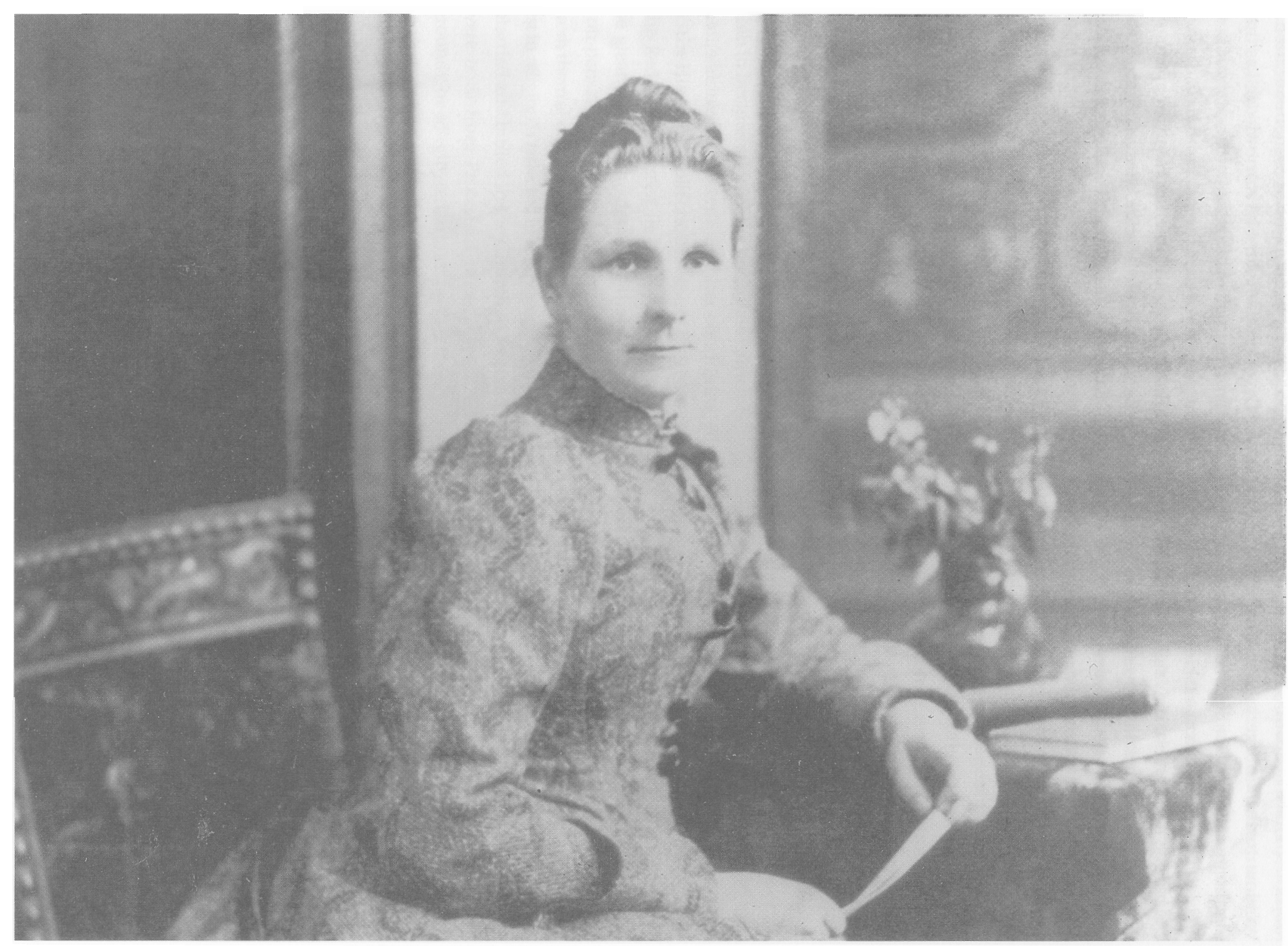




\section{ANNA DAWSON HARRINGTON'S MEMOIR OF HER FATHER SIR WILLIAM DAWSON, 1900}

\section{By Robert H. Michel}

In 1900 Anna Dawson Harrington (1851-1917) jotted down her vivid memories of her father, Sir William Dawson, geologist and McGill Principal. She hoped to breath life into the stilted, impersonal, MS autobiography that her father had completed before his death in 1899. Her notes, while unfinished, give a unique, intimate record of Sir William's personality, interests, daily routines, and family life. They are transcribed here with an account of their origin in the family dispute which preceded the autobiography's publication as Fifty Years of Work in Canada in 1901. The relevant documents are in the Dawson Family Fonds in the McGill University Archives.

C'est en 1900 que Anna Dawson Harrington (1851-1917) écrit ses souvenirs de son père, Sir William Dawson, géologue et recteur de McGill. Elle espérait rendre plus vivante et plus personnel l'autobiographie écrite par son père avant son décès en 1899. Bien qu'incomplet, son récit nous offre un regard unique et intime de la personnalité de Sir William, de sa routine journalière et de sa vie en famille. Cet article présente ses notes dans le contexte de la dispute familiale qui a précédé la publication de cette bibliographie portant le titre Fifty Years of Work in Canada, en 1901. Tous ces documents se trouvent dans le Fond de la famille Dawson aux Archives de l'université McGill.

\section{PART I: BACKGROUND}

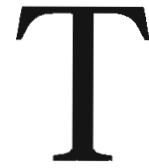

HE SUBJECT OF THIS BRIEF is a short, significant memoir in the McGill University Archives about Sir William Dawson (18201899) by his daughter Anna Dawson Harrington (1851-1917) [Fig. 1.\} Anna wrote it in 1900 to help flesh out her father's draft autobiography. After a serious illness in 1892 and his retirement as McGill's Principal in 1893, Sir William had written his autobiography, conscious of his roles as builder of McGill University since 1855 , creator of Canadian scientific networks, geologist, and anti-Darwinian reconciler of science and religion. At his death in November 1899, he left a MS autobiography which was published in January 1901 as Fifty Years of Work in Canada: Scientific and Educational (Ballantyne, Hanson \& Co., London \& Edinburgh). ${ }^{1}$ The autobiography was edited by Sir William's youngest son, and McGill graduate, physician Rankine Dawson (1858-1913). Its publication sparked controversy among the Dawson children, a lively episode well described by Susan Sheets-Pyenson in her biography John William Dawson: Faith, Hope, and Science

\footnotetext{
1 This comment follows up one on the Dawson Papers (which briefly referred to Sir William's autobiography and Anna's memoir): Robert H. Michel, "An Archival Testament: the papers of Sir William Dawson," Fontanus IX (1996): 125-29. As Susan Sheets-Pyenson remarked to me once, the draft autobiography in the Dawson Fonds differs from the published version; these differences have never been analyzed. Rankine took another draft or copy to England; whether other versions or copies existed is unknown. Anna's notes appear to refer to a draft, which she described as dictated and with different pagination than the McGill copy.
} 


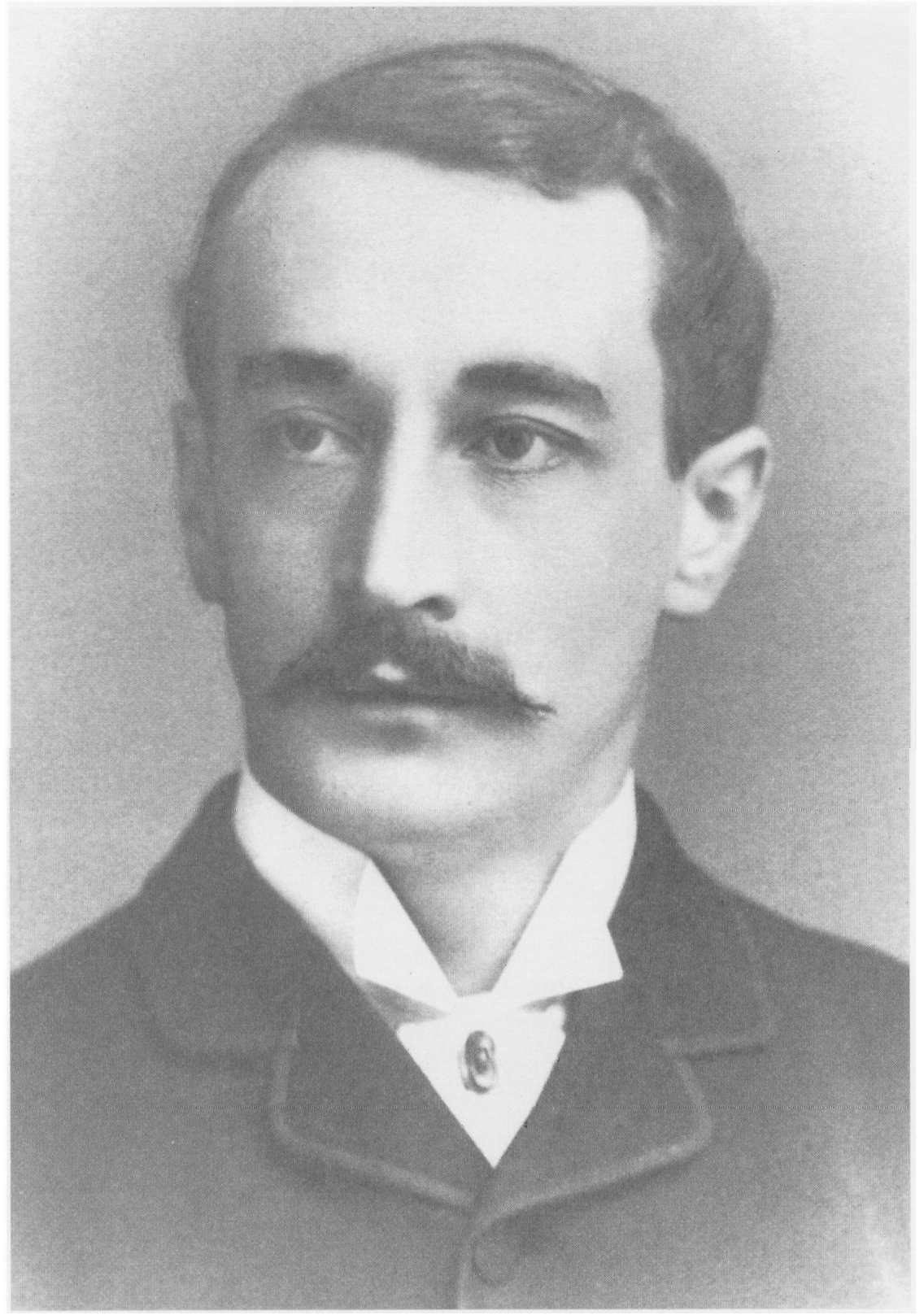

Figure 2. Rankine Dawson, ca 1890 (McGill University Archives, PR027253). 
(McGill-Queen's University Press, Montreal \& Kingston, 1996). ${ }^{2}$ Supplementing that work, this account focuses on Anna's role and gives a full transcription of her handwritten memoir to make it more readily available. The controversy over publication of Sir William's autobiography is documented in the Dawson Family correspondence in the McGill University Archives (MG 1022), particularly between George M. Dawson (1849-1901), living in Ottawa, and his sister Anna Dawson Harrington, living in Montreal, and to a lesser extent in the correspondence of their mother Margaret (1836-1907), and brothers Rankine and William (1854-1944) and sister Eva (1864-19??).

The conflict was over whether or not to publish Sir William's MS as he had left it or to substantially improve it. The youngest son Rankine (Fig. 2), living in London, England, maintained (correctly) that their father had wanted his autobiography to be published soon after his death, ${ }^{3}$ with a minimum of editing; that he had written it as his own record of his life rather than as the basis for a biography by someone else. Rankine and his father had often been at odds with each other; Rankine's career had ups and downs and, on occasion, Sir William had found Rankine too worldly and concerned with moneymaking schemes. However, in 1899, Rankine had visited his father and had probably promised to help publish the autobiography. Indeed, at the same time, Rankine was already representing his father in London, regarding the possible publication of "The Seer of Patmos" by Hodder and Stoughton. ${ }^{4}$ After Sir William's death on November 19, 1899, Rankine at first deferred to his older brother George's advice but eventually claimed that he, not George, had been entrusted by their father with the task of publication. Over the course of 1900, Rankine, back in London, prepared to publish the MS.

Opposing Rankine were the like-minded George and Anna, Sir William's oldest children and the ones who had been closest to him. As his father's collaborator in geological research and himself an eminent geologist, George would have made a more likely editor than Rankine; in fact George may have suggested his father write the autobiography. But George could spare little time from his duties as Director of the Geological Survey of Canada. Likewise, Anna could do little because of her family responsibilities. Although Anna felt her lack of university training had left her at a disadvantage compared with her brothers, ${ }^{5}$ she dealt with them as an equal and did not hesitate to give her opinions on the faults of the autobiography. George and Anna agreed the MS autobiography was too dry, limited, dull, modest, misleading, impersonal, over-burdened with quotations from their father's lectures, and lacking in anecdote and narrative interest. It was not, Anna concluded, a good portrayal of the beauty of his career and life. Written in Sir William's decline, the text did not convey his achievements or character. ${ }^{6}$ Ideally, George and Anna would have preferred to commission a full-fledged biography. They considered McGill history professor C.W. Colby as a potential biographer, or at least as someone who might improve the MS autobiography. In October 1900 Anna and her mother lent Colby a MS draft of

2 Susan Sheets-Pyenson, John William Dawson: Faith, Hope and Science (Montreal: McGill-Queen's University Press, 1996), $207-11$.

3 Five weeks before Sir William died, he wrote George that the autobiography would be turned over to him "at my early demise;" that Rankine had promised to give whatever help might be needed for publishing; and noted "please observe, however that in such matters, prompt issue is a vital point..." Letter from Sir William Dawson to George Dawson, October 9, 1899, McGill University Archives, MG1022, C55.

4 Letters from Sir William Dawson to Rankine Dawson, December 21, 1898; January 17, 1899; March 28, 1899, MG1022, C68.

5 Letter from Anna Dawson to Rankine Dawson, November 21, 1898, MG1022, C68.

6 Letters of George Dawson, December 1899 to February 1901, MG1022, C55; passim. Letters of Anna Dawson, December 1899 to February 1901, MG1022, C62, C63; passim. Sheets-Pyenson, John William Dawson, 209-10. 


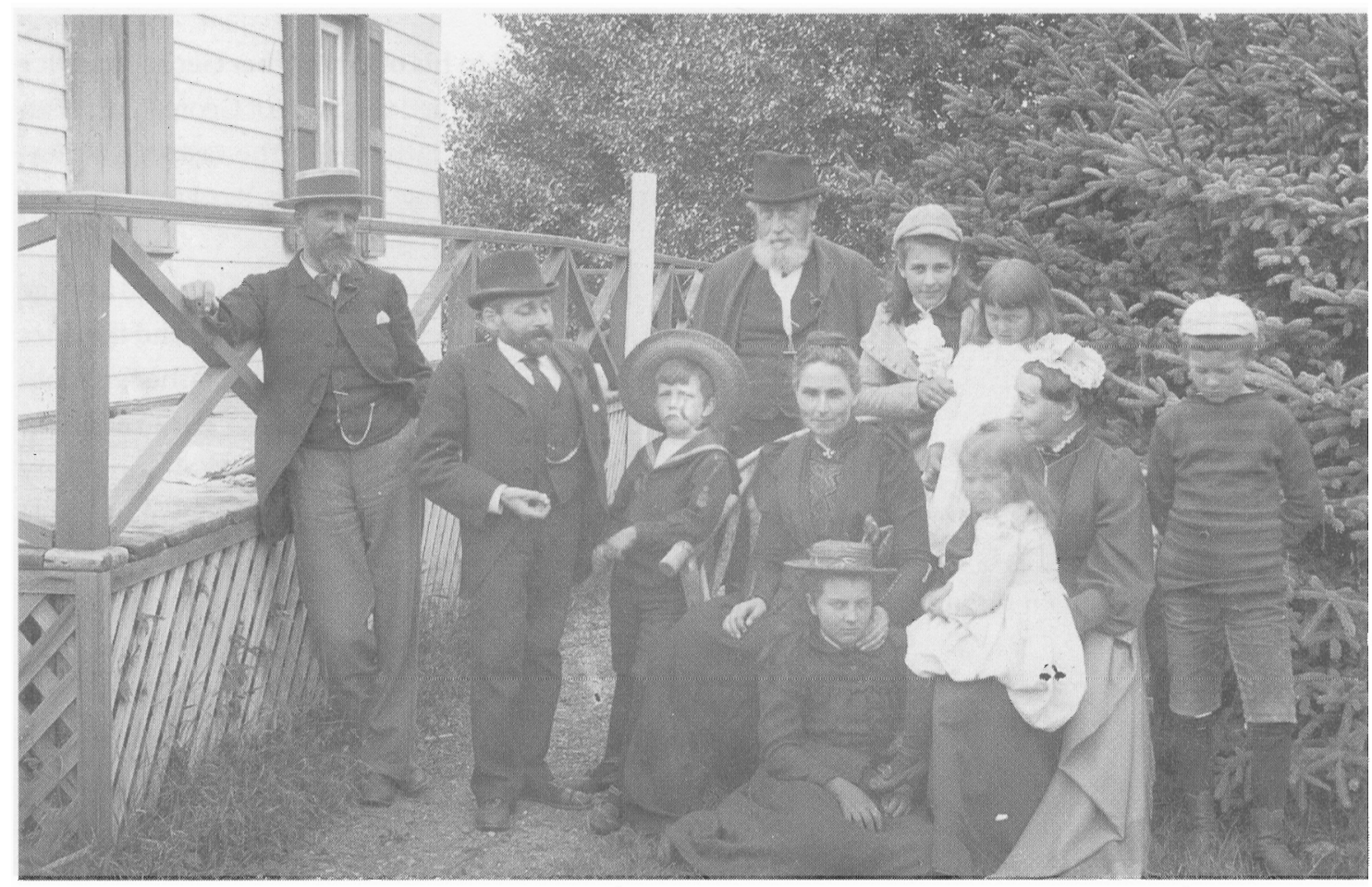

Figure 3. George Dawson, Sir William and Lady Margaret Dawson, Anna Dawson Harrington, B.J. Harrington and their children, ca 1890s, at Little Métis, Québec (McGill University Archives, PR027302).

the autobiography but nothing seems to have come of this. ${ }^{7}$ Failing a professional biography, George and Anna aimed, at the very least, to supplement the existing autobiography with letters and anecdotes which would firmly establish their father's contributions to science and education and portray his personal and spiritual qualicies.

Accordingly, in the summer and fall of 1900 , George and Anna corresponded passionately but vaguely about ways to improve the autobiography. To counteract its dry, impersonal tone, they decided to write down their memories of their father. They probably intended to forward these notes to Rankine to be incorporated in the book, which they were slowly coming to realize he intended to publish, with or without their collaboration. While this comment focuses on Anna's memoir, George's own brief notes concur with Anna's portrait of a caring, patient, instructive parent. ${ }^{8}$ Anna may have been more driven to write than George. She was struck by her father's importance and touched even by his stilted autobiography: "Indeed in reading over details of his life, the beginning always seemed prophetic of his later years, so truly \& unswervingly did he pursue the light

7 Letters of Anna Dawson to George Dawson, June 11, 1900; letter of Margaret Dawson to George Dawson, October 10, 1900, MG1022, C55.

8 George Dawson's biographical notes on his father, McGill University Archives, MC 1022, C81.

9 From a separate note with Anna's memoir, McGill University University Archives, MG1022, C64.

10 Letters from Anna Dawson to George Dawson, August 6, 1900; November 6, 1900; November 28, 1900; December 4, 1900, McGill University Archives, MG1022, C55. 
given to him. ${ }^{\prime \prime}$ By August 1900 Anna decided to write about her father and was jotting things down as late as November or December 1900, while lamenting she had no leisure to write much. ${ }^{10}$ Their mother, Margaret Dawson, wrote to George that she thought Anna could contribute a character sketch of Sir William to the planned book, if only she could spare time from her ceaseless chores. ${ }^{11}$

Yet neither George nor Anna produced enough about their father in the year after his death to alter the autobiography significantly. The editing task and initiative as to publication fell by default to Rankine. While Anna and George tried to think of ways to improve the book and denounced Rankine for ignoring their views, George even threatened legal action to stop publication. Publication rights probably belonged to the widowed Margaret Dawson, who hoped above all to avoid family strife. Rankine quietly brought out the autobiography, Fifty Years, in January 1901 in Britain. It was barely a year after Dawson's death. The impractical and rebellious son had defied his more devoted siblings and became the one to memorialize their father. George and Anna decided not to take steps to have the book withdrawn since this would have meant involving and upsetting their mother and tarnishing their father's memory. Almost immediately after publication, the autobiography controversy became irrelevant: George died suddenly in Ottawa on 2 March 1901. In Rankine's defence, he got the job done. It seems unlikely that a comprehensive biography or improved autobiography could have been produced without extensive research. And imperfect as it was, Fifty Years was well received by those to whom Rankine presented $\mathrm{it}^{12}$ and perpetuated Sir William's vision and life across the next century. Wisely, the family preserved all its papers and, starting in the 1920s, gave them to McGill repositories, where they have been used extensively, especially since the 1970s, with the expansion of research in Canadian history.

Anna did not write her memoir in vain. A century later, its unique information about Sir William's relations with his children and personal routines was mined, not only by Sheets-Pyenson for her biography but also by Cynthia S. Fish, in "Images and Reality of Fatherhood: a case study of Montreal's Protestant Middle Class, 1870-1914," (Ph.D thesis, History, McGill University 1991). Sheets-Pyenson used Anna's memoir as an important source for her discussion of Sir William's family life while Cynthia Fish explored how the memoir revealed him as one of the enlightened Victorian fathers in her study (Fig. 3). Both quoted parts of Anna's memoir and found it shed significant light on Sir William's personal side. With different emphases (and, of course using other sources, mainly correspondence), they noted the memoir's value as a source for family life, attitudes and discipline, and for Sir William's conscientious care for the upbringing, education and entertainment of his sons and daughters. ${ }^{13}$

Because of its documentary value, exemplified by its quotation and use by these two scholars, Anna's memoir is worth publishing in full here. Besides portraying her father, the memoir reflects Anna herselt. She deserves notice on her own account and left a sizable documentation of her own life. Her youthful writing indicates she was creative, introspective and romantic. Like George, unlike Rankine, she was close to her father. Her diary of 1865 records her travels with her father to Europe; he carefully

11 Letters from Margaret Dawson to George Dawson, September 4, 1900 and undated letter, McGill University Archives, MG1022, C55.

12 Rankine Dawson, incoming letters, 1901, MG 1022, C68.

13 Sheets-Pyenson, John William Dawson, 11, 91-92; Fish, "Images and Reality": 280-281, 286 n. 62, 290, 292 n. 78, 298. Fish noted that Sir William involved himself in his children's spiritual upbringing by the time they were about three, far earlier than the other fathers in the group she studied; as well that in conflicting directly, Sir William and Rankine were unique among the fathers and sons in her sampling: 303-306 
explained all the historical sites to her (and even recorded the trip in his Fifty Years $).{ }^{14}$ She inherited her father's intelligence and spiritual and rational attributes yet, like many educated women, she had to spend most of her energy looking after her family. A few generations later, she might have become a scientist herself. Instead, while George was his father's chief intellectual ally, Anna was his greatest support at the family level. She also dealt with some of his correspondence and illustrated many of his geological books and articles, assisting in many ways until her father's death. George wrote her that it was a great comfort to know she had been "able to help so much during all father's failing years.... you were able to work with him \& help him in a way none of the rest of us could. It has been a sacrifice to you in various ways no doubt, but one which I feel you have no cause to regret." 15

In 1900, Anna wrote brief notes about Sir William in the face of exhausting daily demands. She was forty-nine years old, married to McGill Professor Bernard Harrington (1848-1907), with seven children ranging from fairly young to early twenties. Two other children had died at ages eleven and seventeen. ${ }^{16}$ Running a household on her husband's modest salary and helping her widowed mother sort out her affairs, she emerges from the autobiography conflict as an intelligent, stable influence on her antagonistic brothers George and Rankine - agreeing with George that her father deserved a better memorial than his autobiography but anxious that no public disagreement mar her father's memory and mother's peace of mind.

Anna's memoir, while unfinished, may be the most intimate existing record of her father. Its direct, informal language and personal point of view sharply contrast with the ponderous, impersonal Victorian style in which Sir William penned his autobiography. From the privacy of the home, she gave a unique view of Sir William, revealing a father who unlocked the doors of knowledge to her as freely as to his sons. Anna's recollections about her father began self-consciously, by referring to images graven on her youthful memory. She had strong early impressions from the early years that the Dawsons lived in the greystone East Wing of the McGill Arts Building, when she was around ten and her father forty. She particularly remembered her father working in the family garden and laying out the grounds of the McGill campus and its avenue in the 1850 s and 1860 s, still recognizable today. (Sir William improved the grounds partly to make the University more viable and attractive to the Montrealers whose support he needed.) Anna recorded her father's sentimental side - his love of children, as well as his role as parent, teacher, and companion on outings; his story telling, generosity, and rare but effective temper. She also noted his practical and methodical sides; how he left instructions about his worldly affairs before traveling and kept track of his busy life by using a pocket notebook to keep track of appointments and things to be done. Indeed, his secret of success as an administrator foreshadowed modern time-management theory; he dealt with minor questions and details at once as soon as they came up. The memoir concentrates on the years before Anna was an adult; one wishes for the unwritten continuation into later years.

Anna's letters included a few more glimpses of her father, some points of which she would cover

\footnotetext{
14 Some of Anna's early writing is described briefly in Robert Michel, "Diaries from the McGill University Archives - a Sampling," Fontanus $V$ (1992): 42-44.

15 Letter from George Dawson to Anna Dawson, December 3, 1899, McGill University Archives, MC1022, C62.

16 Anna herself would be the subject of a brief memoir by her daughter Lois Winslow-Spragge, who transcribed the correspondence between her parents (1875-1907), wrote about her uncle George Dawson and gave numerous family papers to the McGill University Archives, ca. 1969-1974. Lois Winslow Spragge wrote of her mother: "There were times when sorrow fell heavily upon B.J. (Harrington) and Anna, as it did in 1888 and 1894, when they lost their two oldest children, Eric and Edith. But Anna never gave in, one never saw tears - it seemed as if the words ' 1 triumph still if Thou abide with me' were always singing in her heart." Introduction to the transcription of Anna's letters to Bernard McGill University Archives, MG 1022, C64.
} 
in her memoir. Writing to George on 6 November 1900, she feared (correctly) that Rankine might already be involved with a publisher and spurred herself and George to write their recollections without delay: "Think of his gardening: his bird-stuffing, (who taught him that?) his sketching: I have a hundred recollections of the garden. If I could only get a day to reflect but $I$ am too tired at night \& by day I just fly before the gale of life, $\&$ to steer and trim the sails seems all I can do - \& you are much the same." 17 In a letter to Rankine, Anna argued that any account of Papa would be incomplete without mention of his gardening, of his interest in children, of his always having little books to give away, of his keeping a kind of bank for needy students, of his fatherly relation to his employees, his excursions with students, his pleasant jokes and other attributes which would show him intimately, as the reader would wish to know him. ${ }^{18}$ On 9 December 1900 she wrote to George, sadly remembering her father's final days a year earlier: "One misses Papa at Xmas time, he was always so anxious to purchase for everyone $\&$ never seemed to find it a bother, or to lose his sense of interest in it until last year. He used to begin quite early \& talk about it \& what books were to be got. Always books for all the College Janitors, \& for all the young people a perennial supply. Last year I said one day by way of starting a pleasant topic.... We must soon begin to think of Xmas. He replied, I have done with Xmas. It started \& surprized me so \& was indeed the end of his many loving cares for us." 19

\section{PART 2: ANNA DAWSON HARRINGTON'S MEMOIR OF SIR WILLIAM DAWSON 20}

[Page 1] Ones early recollections are not of a continuous life, but rather like a series of vignettes picturing a few figures or incidents in clear relief \& fading into indefinite spaces. My first clear recollection of my father is one of these. A child of about $8-$ crossed out: "surrounded by an atmosphere"] a day of [illegible word] \& preparation - my older brother \& myself [illegible word] with others in a sitting room all the features of which are clear to me \& our father coming to us through the door[?] a tall thin figure somewhat stooping at the shoulders with clean shaven face \& clear sharp features. The little gifts he brought us raised glass half filled with little coloured sweeties, the opening covered with a seal of red velvet - that is the whole picture.

The next series of remembrances is connected a good deal with "sweeties" \& fruit - brought home to us children when my father went to town, \& pictures shown us, or little stories told, that were not like other pictures or other stories. In the more than busy life that Papa entered upon in Montreal, he still found time for the children. At an early age he insisted upon us coming to table, which was a great education for us, \& he always talked to us or with us so that we fell in the conversation, \& we quite understood that any affairs mentioned before us, must not be spoken of out of the family. Papa was fond of jokes $\&$ often repeated odd stories, or quotations the source of which I did not recognize, till long years after. One or two passages from Hudibras were amongst these,

17 Letter from Anna Dawson to George Dawson, 6 November, 1900, McGill University Archives, MG 1022, C55.

18 An undated copy of this letter to Rankine is among George Dawson's incoming letters for 1900, indicating Anna dealt with Rankine in close alliance with George. McGill University Archives, MG 1022, C55.

19 McGill University Archives, MG 1022, C55.

20 The memoir is among the Anna Dawson Harrington papers, McGill University Archives, MC 1022, C64. 
several from Byron, from Pickwick Papers - \& Scott's novels.

[Page 2] He constantly gave us books, of all kinds from a set of Mrs. Sherwood's somewhat stilted tales ${ }^{21}$ to a beautiful illustrated copy of the Arabian Nights that illuminated that period of our Childhood.

On Saturday morning he often went to town about little business matters, \& I not infrequently was his companion. I used to feel great pride in having him introduce me as "his only daughter," which I was for a number of years \& was delighted to see the interior of printing offices, banks, the Post Office $\&$ wonderful places, all of which he would explain to me as we went along. On several occasions I spent a morning at his office in the old Burnside Hall \& the Normal [School] and examined with much interest a stuffed monkey \& a few other curiosities which were the nucleus of the present museum. [Crossed out: "he did not speak much to me"] I remember his explaining an electrical machine which made sparks, $\&$ a stool with glass legs in a most satisfactory manner.

He also frequently took short excursions on Saturday to places of interest, geologically or botanically and my brother \& I used to go also - when we would be set to hunt for some rare violet to be found in that locality, or to search for snail shells on a hillside or trilobites in the rocks or leda[?] shells in the blue clay. Whatever he was himself searching for or thinking over, he never was too occupied to answer our questions or look at our discoveries, \& indecd I think we felt ourselves distinctly members of the expedition: St. Helen's Island with its geraniums and old block house; Brickfields at what used to be called the Glen. Later on, when building excavations disclosed the remains of the old Indian Hochelaga, we went every morning before breakfast to see what had been uncovered, \& to look over the remains the workmen were rewarded for carefully preserving.
Another pleasure that stretches over long years was Papa's love of gardening. From his garden in N[ova] S[cotia] he brought roots \& plants \& seeds of favorite sorts, \& not long after he arrived at $\mathrm{M}$ [meaning either McGill or Montreal], he was to be seen with muddy boots $\&$ turned up trousers measuring out and tracing the form for garden beds in an unsavoury slough that lay at the foot of the terrace on which our home stood. Two Irishmen were at his bidding \& were digging an oval trench \& removing the boulders that were strewn about. Some of the larger ones were built into a rough garden seat $\&$ before long

[Page 3] order came out of chaos. A cinder walk surrounded an oval bed. Shrubs were planted, \& next spring, morning after morning, my father was out between six $\& 7$, with us at his heels sowing seeds, carrying water for plants from the pretty little brook that then flowed through the College grounds, covering transplanted treasures \& so on. Many will remember the dear old fashioned garden, not trim $\&$ precise but full of flowers that might always be liberally picked, while fruit trees stood here \& there, $\&$ vegetables at the other end. Working in this garden was one of the few recreations of my father for many years, \& his early bulbs, green peas \& rhubarb were matters of most absorbing interest. For several years he helped us to prepare, [hoe it?], \& sow seeds of annuals about April, \& they flourished mightily in our sunny hall window \& attained great distinction when put in the garden. He never lost his interest in gardens [crossed out: "though for the last few years he"], looking after the making of a little border at the back of his University Street house and even in his last summer at Metis, walking feebly \& with support to our Metis garden to see some new poppy, or special rose.

[Crossed out: "In this connection"] The College grounds he gave unremitting care himself, planned

21 Mrs. Mary E. Sherwood (1775-1851) was a prolific English author of moralistic stories for children, collected in various editions, including sets in 1860 and 1861, which Anna might have seen when she was nine or ten. See M. Nancy Cutt, Mrs. Sherwood and her Books for Children (London: Oxford University Press, 1974). 
\& paced \& laid out walks about them, had rustic bridges built, \& trees planted. The avenue was leveled under his direction \& all the trees planted under his eye. In his occupation he was surveyor, landscape gardener, nurseryman \& chief paymaster also. He respected the great natural beauty of the College grounds [crossed out: "there was a large boulder with pretty"] \& made the most of it with an artist's eye [crossed out: illegible words]. The needs of new buildings have done away with one after another of these. The few fine oaks, the pretty brook running through the hollow, the level places where groups of trees were placed. All considered.

He was always most liberal with money, for us children to ask meant to get, but for that very reason we felt it a point of honour not to ask except on rare occasions, at least not without consulting mother, who required the reasons, pro \& con, for the expenditure.

[Page 4] Papa had a quick temper, though there were very few occasions when he let it appear, but he had no sympathy for practical jokes, \& several times when something of that nature transpired, he would speak hotly to us, which made the more impression because he was usually so gentle and courteous to us. As to games, he took no interest in them or very little. [Crossed out: "They were not the rage of his day when life was taken a little more seriously."] He did teach us to play draughts, \& used sometimes to play with us when we were quite small. Music he took no interest in. Indeed I think he regarded a musical inclination as rather a hindrance to more serious work, \& I am sure he regarded a musical student as one with a drawback to success. He sometimes sang in church but much out of tune. There were however some few tunes which were associated with incidents of his youth, \& if one of these was played, it never failed to draw him from his library with some expression of pleasure or approval.

He had little art-training but he did a great deal of drawing \& colour in chalk or water colour sketches of places he had been, usually those required to illustrate some geological or natural fact for book or lecture. He made endless diagrams for class work or lectures of every kind: zoological, botanical, Geological or of Egypt or the Catacombs. He gave me my first ideas of sketching from nature, in which he much encouraged me. He also drew many illustrations for his books, sometimes on the wood, for engraving.

In common with mother [?] he was rather fond of sweetmeats, \& usually had candies of some kind in one of his desk drawers, which was well known to his grandchildren, \& after he ceased to be able to shop for himself, he always reminded us to have it replenished. Peppermints he was very fond of.

He always was an early riser, usually downstairs by 7 o'clock \& doing a great deal of his daily correspondence before the $8 o^{\prime}$ 'clock breakfast. He was very systematic \& regular in his habits \& never seemed to put off anything. It was the secret of his never neglecting little things, that he always attended to them at once.

[Page 5] He was never too busy to add the smallest commission for any of us to his town list and anything wanted by mother had only to be hinted at to be accomplished, or ordered. He always kept a memo book \& every engagement was noted in it that he had - if this book was missing, it was a calamity, \& we all flew to assist in the search for it. All his business matters were kept in perfect order, \& if he was leaving home for a time he would give my mother, or if she were going, one of us, exact directives about key of safe, bank book, etc. \& a list of any insurance or payment that would fall due within the near future. [Crossed out: "This was so much his habit to thus wind up his affairs \& give us that"] When he was stricken with pneumonia \& insisted upon giving directives, \& orders as to what should be done if he did not recover, the doctors demurred as to the effect of the effort, but we said it was his habit, and he would be uneasy till he had arranged everything. When my brother came he clearly and rapidly went into every detail, \& they were noted down; then with perfect peace \& quiet he dismissed all the affairs of life, \& 
gave himself for life here or life hereafter in to God's hands. This illness when he was 72 was the first time I ever remember him being confined to bed [Crossed out: "I never knew him to be in bed from one day to another"] except on one occasion when he had fallen heavily \& wounded his head badly, \& the Doctor obliged him to spend 8[?] days quietly in bed as a precaution, and very hard work he found it.

He was always much interested in children, never given to much petting or caressing but always so courteous \& considerate. He seemed to respond to any want or wish of a child by a turning toward them, $\&$ a giving of himself to them, in a kind of fellowship, that only is possible to one whose purity of heart $\&$ softness of eye gives

[The MS ends here.]

\section{ABOUT THE MANUSCRIPT}

The memoir was written on 5 pages of varying sizes, in pencil and ink (the preliminary paragraph quoted below was on an additional page). The handwriting and line-spacing indicate it was probably written in three sittings; in the first sitting, scrawled none too legibly in pencil; in the next two sittings, more legibly and carefully in ink. Anna's letters to George indicate the dates of composition were from about August to December 1900. In this transcription, page breaks are indicated; line breaks are not. There are various cross-outs in the text; they are included between brackets, unless they are merely alternative words which do not alter the sense. Except for ampersands (\&), obvious abbreviations, e.g. P (for Papa) are expanded. The text's punctuation and capitalization are uneven. To avoid run-on clauses, commas have been inserted. Where a new sentence seemed indicated, capitalization has been supplied as well.
Words and phrases guessed at are followed by question marks in brackets. Indecipherable or illegible words are noted between brackets as "illegible word." Anna probably sent her memoir to George Dawson in December 1900. Fish cited the memoir as being among George Dawson's papers in McGill's Rare Book Department; when these papers were transferred to the McGill University Archives in the late 1980 's, they were classified as a work by Anna Dawson, and placed with her papers (MG 1022, C64). Two brief lists of comments, probably referring to the pages of some draft of Sir William Dawson's autobiography (apparently not the copy in the McGill Archives) are with Anna Dawson's memoir, one list being verso on a page of the memoir. (The list is headed by Anna's comment that much of the work in question was "dictated during months of failing health" - perhaps this refers to a draft dictated by Sir William to Anna.)

Anna appears to have warmed up for her memoir of her father with a mysterious paragraph on her very earliest images - which do not include her father. In pencil, it presumably was written at the same sitting as the first paragraph of the memoir transcribed above. In the absence of parents, she apparently goes outdoors, perhaps by the sea in Nova Scotia, about the age of four or younger, before her parents moved from Pictou, N.S. to Montreal in 1855:

"My first recollection has for background - a sense of hush \& calm. In the house. The absence of parents \& [two illegible words]. The going into still streets in care of an unusual guardian. A Sunday morn. For foreground standing on a pier[?] or whey [=quay?] \& first consciously looking out over a wide, water covered [illegible word] the glittering glory[?] of crisp little scenes[?]. The same track widening to my feet. I can see [?] myself a speck gazing [?] and gazing [?] enchanted \& only dimly knew I was being urged to turn homeward." 